\title{
Comparison of Snail-1 and Estrogen Receptor Immunoexpression between Fibroadenomas and Phyllodes Tumors
}

\section{Perbandingan Imunoekspresi Snail-1 dan Reseptor Estrogen antara Fibroadenoma dengan Tumor Filoides}

\author{
Fairuz Fairuz \\ Department of Anatomical Pathology Faculty of Medicine and Health Sciences Universitas Jambi Jambi
}

\begin{abstract}
Fibroadenomas (FA) and phyllodes tumors (PT) are fibroepithelial lesions in the breast, which until now the relationship between the pathogenesis of both have not been ascertained yet. Epithelial cells are thought to be involved in the regulation of changes in the stromal cells in the PT, so it can be estimated that this process is involved in epithelialmesenchymal transition (EMT). This study aims to compare of snail family transcriptional repressor 1 (Snail-1) and estrogen receptor (ER) impression as EMT factors among tumor type (FA, benign PT, boderline PT and malignant PT). This study was an observational analysis with the cross-sectional method. After the histologic grade of the samples was reviewed, immunohistochemistry examination for ER and Snail-1 was performed. Statistical analysis for categorical data was tested by chi-square test. There were 66 samples, consists of 20 FA, 17 benign PT, 16 borderlines PT, and 13 malignant PT. A significant difference in the loss of ER expression in borderline and malignant PT was found compared to FA and benign PT. This is inversely proportional to the snail-1 expression, where the expression was high in borderline PT and malignant PT stromal cells. This could support the consideration of the pathomechanism regulation of epithelialmesenchymal cell transition changes in FA with PT, where Snail-1 is one of the proteins in the regulation of the EMT and RE processes acting as an inhibiting factor in transcription factors in the mechanism of EMT occurrence.
\end{abstract}

Keywords: Estrogen receptor, fibroadenomas, pyhllodes tumors, snail-1

\section{ABSTRAK}

Fibroadenoma (FA) dan Tumor Filoides (TF) adalah lesi fibroepitelial di payudara, yang sampai sekarang belum dipastikan hubungan patomekanisme antara keduanya. Sel epitel diduga terlibat dalam regulasi perubahan sel stroma dalam TF, sehingga dapat diperkirakan bahwa proses ini terlibat dalam transisi epitel-mesenkimal (TEM). Penelitian ini bertujuan untuk mengetahui perbandingan imunoekspresi dari snail family transcriptional repressor 1 (Snail-1) dan reseptor estrogen (RE) sebagai faktor TEM antara berbagai jenis tumor (FA, TF jinak, TF boderline dan TF ganas). Penelitian ini merupakan studi observasional analitik dengan metode cross sectional. Setelah nilai histopatologis sampel dinilai, dilanjutkan dengan pemeriksaan imunohistokimia untuk RE dan Snail-1. Analisis statistik untuk data kategorik diuji dengan uji chi-square. Terdapat 66 sampel, terdiri dari 20 FA, 17 TF Jinak, 16 TF borderline dan 13 TF ganas. Didapatkan perbedaan yang signifikan pada hilangnya ekspresi RE di sel epitel duktuli antara TF borderline dan TF ganas dibandingkan dengan FA dan TF jinak, yang menunjukkan hilangnya pengaruh RE pada TF borderline dan TF ganas. Hal Ini berbanding terbalik dengan ekspresi Snail-1 yang ekspresinya tinggi pada sel stroma borderline dan TF ganas. Hasil mendukung pertimbangan adanya patomekanisme regulasi perubahan transisi sel epitel-mesenkimal pada FA dan TF, dengan Snail-1 merupakan salah satu protein dalam regulasi terjadinya proses TEM sedangkan RE berperan sebagai faktor inhibisi pada faktor transkripsi dalam mekanisme terjadinya TEM.

Kata Kunci: Fibroadenoma, reseptor estrogen, snail-1, tumor filoides

Correspondence: Fairuz Quzwain. Department of Anatomical Pathology Faculty of Medicine and Health Sciences Universitas Jambi, Jl. Letjend Soeprapto No.33 Telanaipura Jambi Tel.081320778463/0741-60246Email:fairuz.quzwain@gmail.com 


\section{INTRODUCTION}

Fibroepithelial breast lesions are a group of breast neoplasms ranging from benign to malignant, in which each shows a different level of stromal proliferation in relation to the epithelial compartment (1). Fibroadenoma (FA) and phyllodes tumor (PT) are fibroepithelial lesions in the breast that, until now, the relationship between the pathogenesis of both has not been confirmed. Fibroadenoma is a benign neoplasm that is mainly found in young women, rarely found after menopause, usually found in the upper outer quadrant, well-restricted lobes, easily removed from surrounding tissue, and usually found as a single lump, but $10 \%-15 \%$ of women who are suffering from FA have several lumps in both breasts $(2,3)$.

Histologically, FA has several variants, most of which do not pose a diagnostic challenge, but cellular FA and juvenile FA types can have features similar to PT and, admittedly, often have different assessments. Cellular FA and juvenile FA are benign biphasic tumors, commonly known as different entities. Cellular FA has FA architecture with gynecomastia cellular stroma and increased stromal cellularity. Until now, it has been difficult to distinguish benign PT from cellular FA because increased cellular stroma is a prominent feature of both. However, the difference between FA and PT is important because the treatment and prognosis are different. Phyllodes tumors represent a spectrum of lesions with various clinical behaviors and are assessed as benign, borderline or malignant based on histological feature variants according to the World Health Organization (WHO) recommendations. Several recent studies have significantly enhanced our understanding of the pathogenesis of fibroepithelial lesions, highlighting FA as a true neoplasm $(2,4)$.

Although PT is histologically classified as a biphasic tumor consisting of epithelium and stroma, several studies have shown that FA and PT are mostly stromal tumors with unclear epithelial components, especially in malignant PT, and reported that the stromal and epithelial components in PT are neoplastic. The epithelial-mesenchymal transition (EMT) is thought to be related to the epithelial and stromal components in PT. The basic concept of EMT is that epithelial cells are morphologically and functionally converted into mesenchymal cells, which in turn induce various cellular events. When EMT is induced in vitro, the cell's shape changes from round to ovate to spindle, cell polarity disappears, and tumor cells are separated into individual cells. Cellular phenotype signs also change during EMT, which follows the loss of junction cell proteins (E-cadherin), desmosomes, integrins, and cytoskeletal elements such as cytokeratin and Snail $(5,6)$. Snail transcription factors are regulated in cancer cells and are thought to be related to increased tumor migration and invasion through EMT induction (7).

Estrogen activation is also thought to encourage the development of breast cancer. The presence of growth factor- $\beta$ conversion (TGF- $\beta$ ) usually counteracts the action of ER- $\alpha$, which also induces an EMT program and promotes the spread and chemoresistance of breast cancer. The impact of the EMT program on non-genomic ER- $\alpha$ signaling is still unknown. Disruption between Snails and ER through the role of TGF-B is considered to be related to the EMT process $(8,9)$. This study aimed to compare of snail family transcriptional repressor 1 (Snail-
1) and estrogen receptor (ER) impression as epithelialmesenchymal transition factors among FA, benign PT, boderline PT and malignan PT.

\section{METHODS}

A total of 66 paraffin blocks that consisted of 20 FA, 17 benign PT, 16 borderline PT, and 13 malignant PT were obtained from the anatomical Department of Pathology of Abdul Manap Hospital, in a period of 2015 to 2017. The PTs were divided based on the WHO 2012 classification. All cases diagnosed based on conventional histological parameters were included in this study. The patients' age, tumor location, and relevant details were obtained from the pathology report. All cases were histologically classified based on stromal cytology atypia, stromal hypercellularity, number of mitosis, stromal overgrowth, tumor necrosis, and tumor margins. All tumor specimens were fixed in $10 \%$ formalin and embedded in paraffin according to standard procedures. Immunohistochemical staining was done manually to determine the expression of selected biomarkers in the stroma using the DAB horseradish chromogen. Thick sections of $4 \mu \mathrm{m}$ were placed on a positively charged slide and heated at $60^{\circ} \mathrm{C}$ for 30 minutes. Deparaffinization in xylene and rehydration through multilevel alcohol was followed by treatment by taking antigens for 40 minutes at $98^{\circ} \mathrm{C}$. The sections were then cooled at room temperature and incubated with a blocking agent, hydrogen peroxide for 10 minutes, followed by incubation of primary antibodies for 30-60 minutes at room temperature. Immunostaining was carried out with the following antibodies, namely anti-ER (SP1 clone, diluted 1:200, Thermo Scientific) and anti Snail1 (diluted 1:50, Sigma-Aldrich). Estrogen receptor staining is interpreted as positive when tumor core staining is detected and Snail-1 when cytoplasmic staining is detected. The number of positive cells was evaluated in 10 high-power fields (40x) for each histology section and counted as a tumor positive cell percentage. $((-)<0-20 \%$, $(+)>20 \%)$. Statistical analysis $p$ values were calculated using the Chi-Square statistical tests for categorical data (table 2). The level of significance was based on $p<0.05$. Statistical analysis was performed with SPSS software for windows (V.24.0).

\section{RESULTS}

A number of 69 tumor samples were obtained from various grades of gradation. After being evaluated, three samples were excluded because they did not meet the inclusion criteria. Table 1 illustrates the overall characteristics of the study subjects that are age (years), tumor size $(\mathrm{cm})$, location, and solitary/multiple. Table 1 shows us the clinical characteristic of FA and PT. All patients had no specific age in this tumor (17-69 years), various tumor size between 1.2 to $15.7 \mathrm{~cm}$, more solitary $(89,4 \%)$ in accordance with various literature and the location of the tumor was more commonly found in the left breast. In this study we even found PT less than $2 \mathrm{~cm}$ in size.

Table 1. Clinical characteristic

\begin{tabular}{lr}
\hline \multicolumn{1}{c}{ Variable } & $\mathrm{N}=66$ \\
\hline Age (years) & \\
Mean \pm SD & $41.16 \pm 12.908$ \\
Median & 42.00 \\
\hline
\end{tabular}


Table 1. Clinical characteristic (Cont.)

\begin{tabular}{lr}
\hline \multicolumn{1}{c}{ Variable } & $\mathbf{N}=66$ \\
\hline Range (min-max) & $17.00-69.00$ \\
Location & \\
Right & $21(31.8 \%)$ \\
Left & $45(68.2 \%)$ \\
Size (cm) & \\
Mean \pm SD & $6.79 \pm 2.965$ \\
Median & 7.05 \\
Range (min-max) & $1.20-15.70$ \\
Type & \\
Solitary & $59(89.4 \%)$ \\
Multiple & $7(10.6 \%)$ \\
Diagnosis & \\
Malignant PT & $13(19.7 \%)$ \\
Borderline PT & $16(24.2 \%)$ \\
Benign PT & $17(25.8 \%)$ \\
Fibroadenoma & $20(30.3 \%)$ \\
\hline
\end{tabular}

The comparison of ER and Snail-1 immunoexpression can be seen in Table 2. The highest ER immunoexpression variable is in the FA epithelium (75\%), and Snail-1 is in PT malignant stromal cells (100\%). Estrogen receptor immunoexpression is constant in the epithelium, and Snail-1 is constant in the epithelium and stroma. For statistical analysis, ER on epithelium and Snail-1 on epithelial and stromal cells obtained that $p$-value was less than 0.05 , which means that there are differences among groups for all variables. Loss of immunoexpresion of ER on high grade PT epithelial cell in accordance with the loss of the glandular appearance at PT, and high immunoexpression of Snail-1 occur in hypercellular of stromal cell PT. This can be considered for the influence of ER and Snail-1 on changes in glandular epithelial cells with stromal cells in fibroapithelial lesions. This result show us there was a significant change in the loss of estrogen's influence on PT compared to FA in epithelial cell and the role of snail-1 was increasingly strong in changes of epithelial cell and stromal cell to a higher degree PT.

Estrogen receptor immunoexpression was strong in ductular cells in FA and moderate expression in benign PT. No ER or Snail-1 expression was found in the stromal cells in both (figure 1). This picture is inversely proportional to borderline and malignant PT, where ER expression will disappear and Snail-1 is stronger in malignant PT stromal cells (Figure 2). The loss of the role of ER in PT cells and switching to snail-1 as one of the EMT receptors increases the suspicion of the theory of EMT in the pathomechanism of PT.

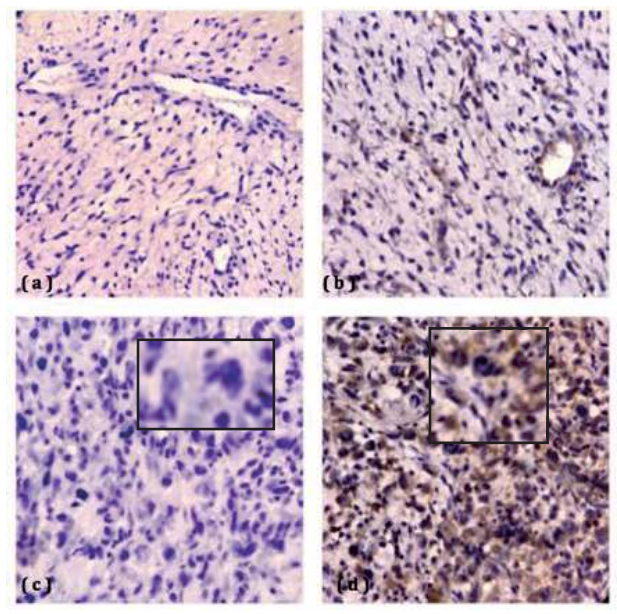

Figure 1. Estrogen Receptor and Snail-1 immunoexpression on FA and PT

Note: (a) ER immunoexpression on FA (b) Snail-1 immunoexpression on FA (c) ER immunoexpression on benign PT (d) Snail-1 immunoexpression on benign PT ( all at 40x magnification)

This picture is inversely proportional to borderline and malignant PT, where ER expression will disappear and Snail-1 is stronger in malignant PT stromal cells (Figure 2). The loss of the role of ER in PT cells and switching to snail-1 as one of the EMT receptors increases the suspicion of the theory of EMT in the pathomechanism of PT

Table 2. Comparison of estrogen receptor (ER and snail-1) immunoexpression among tumor type

\begin{tabular}{|c|c|c|c|c|c|}
\hline & $\begin{array}{l}\text { Fibroadenoma } \\
\qquad \mathbf{N}=\mathbf{2 0}\end{array}$ & $\begin{array}{c}\text { Benign PT } \\
\mathrm{N}=17\end{array}$ & $\begin{array}{c}\text { Borderline PT } \\
\mathrm{N}=16\end{array}$ & $\begin{array}{c}\text { Malignant PT } \\
\mathrm{N}=13\end{array}$ & $\begin{array}{c}P \\
\text { (Chi Square) }\end{array}$ \\
\hline \multicolumn{6}{|c|}{ Estrogen Receptor (ER) } \\
\hline Epithelial & & & & & $0.000^{*}$ \\
\hline Positive & $15(75.0 \%)$ & $8(47.1 \%)$ & $3(18.8 \%)$ & $0(0.0 \%)$ & \\
\hline Negative & $5(25.0 \%)$ & $9(52.9 \%)$ & $13(81.3 \%)$ & $13(100 \%)$ & \\
\hline \multicolumn{6}{|c|}{ Estrogen (ER) } \\
\hline Stromal & & & & & 1.000 \\
\hline Positive & $0(0.0 \%)$ & $0(0.0 \%)$ & $0(0.0 \%)$ & $0(0.0 \%)$ & \\
\hline Negative & $20(100 \%)$ & $17(100 \%)$ & $16(100.0 \%)$ & $13(100 \%)$ & \\
\hline \multicolumn{6}{|l|}{ Snail-1 } \\
\hline \multicolumn{6}{|l|}{ Epithelial } \\
\hline Positive & $4(20.0 \%)$ & $8(47.1 \%)$ & $9(56.3 \%)$ & $0(0.0 \%)$ & $0.004 *$ \\
\hline Negative & $16(80 \%)$ & $9(52.9 \%)$ & $7(43.8 \%)$ & $13(100 \%)$ & \\
\hline \multicolumn{6}{|l|}{ Snail-1 } \\
\hline \multicolumn{6}{|l|}{ Stromal } \\
\hline Positive & $0(0.0 \%)$ & $0(0.0 \%)$ & $13(81.0 \%)$ & $13(100 \%)$ & $0.000^{*}$ \\
\hline Negative & $20(100 \%)$ & $17(100 \%)$ & $3(18.8 \%)$ & $0(0.0 \%)$ & \\
\hline
\end{tabular}




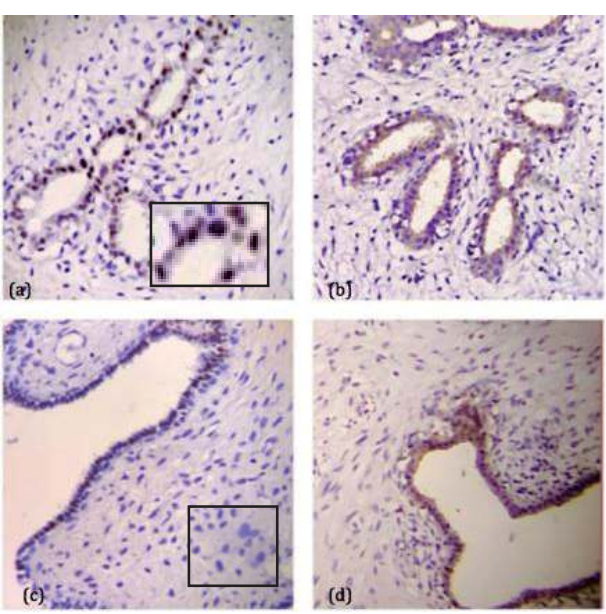

Figure 2. ER and snail-1 immunoexpression on borderline and malignant Pts

Note: (a) ER immunoexpression on borderline PT (b) Snail-1 immunoexpression on borderline PT (c) ER immunoexpression on malignant PT (d) Snail-1 immunoexpression malignant PT (All at $40 \mathrm{x}$ magnification)

\section{DISCUSSION}

Snail is a zinc-finger transcription suppressor that plays a role in the EMT process during embryogenesis and tumor development; and has appeared in various medical studies in recent years. In the N-terminal SNAG domain, Snail works with several co-repressors and suppresses certain target genes, such as the E-cadherin (CDH1) gene. Integrated and complex signaling networks, including TGF- $\beta$, Notch, Wnt, TNF- $\alpha$, and BMPs, which enable Snail, can also induce EMT (10). Snail-1 expression correlates with tumor level, nodal metastases from various types of tumors, and predicts poor outcomes in patients with metastatic cancer. Several studies have shown that Snail causes metabolic reprogramming, affects tumor cells with traits such as cancer stem cells, and increases tumor recurrence, drug resistance, stem cell biology, and in the pathogenesis of metastases $(11,12)$. Some studies show the loss of snail inhibits the growth of pancreatic cells, meningeal, and prostate cancer. In prostate cancer, Snail is necessary for hypoxia-induced invasion and as a potential marker for predicting recurrence. Snail regulates cell growth and energy metabolism through ribosomal

\section{REFERENCE}

1. Hanby AM, Millican-Slater R, and Dessauvagie B. Fibroepithelial Neoplasms of the Breast. Diagnostic Histopathology. 2017; 23(4): 149-158.

2. Krings G, Bean GR, and Chen YY. Fibroepithelial Lesions; the WHO Spectrum. Seminars in Diagnostic Pathology. 2017; 35(5): 438-452.

3. Tan J, Ong CK, Lim WK, et al. Genomic Landscapes of Breast Fibroepithelial Tumors. Nature Genetics. 2015; 47(11): 1341-1345.

4. Zhang Y and Kleer CG. Phyllodes Tumor of the Breast Histopathologic Features, Differential Diagnosis and Molecular/Genetic Updates. Archives of Pathology and Laboratory Medicine. 2016: 140(7); 665-671. protein-mediated by miR-128 S6 kinase 1 (RPS6KB1)/HIF1alpha/PKM2 signaling pathway $(13,14)$. In this study, there was an increase in snail-1 immunoexpression in borderline and malignant stromal cells of PT. Interestingly, some parts of fibroadenoma epithelial cells were found to have a snail-1 expression, but not in stromal cells. The presence of snail-1 expression in PT malignant stromal cells is in accordance with EMT theory about the mechanism of morphogenesis that converts epithelial cells into transient or permanent mesenchymal cells. This process is in accordance with the results of the EMT discussion center in Poland in 2007 and Cold Spring Harbor Laboratories in 2008 that revealed three categories, one of which is related to neoplastic lesions, namely EMT type 3. It occurs in neoplastic cells that previously underwent genetic and epigenetic changes, especially in genes that support tumor cell development. These changes can be in the form of epithelial-mesenchymal transitions or occur because of mesenchymal-epithelial crosstalk $(15,16)$. The influence of hormonal factors is thought to be partly responsible for changes in tumor filodes mesenchymal cells. The alleged role of ER in the EMT process was initially found to decrease ER and PR expression in the incidence of metastases and tumor cell progression in gynecological tumors, breast carcinoma, and prostate (17-19). The decrease in ER function is as inhibition of EMT transcription factors such as Snail1, Slug, and Smad and through regulation of miR-200a/b/429, which suppresses ZEB1 and SIP1 and will then increase E-cadherin expression. This increase in E-Cadherin expression is the main pathway of ER- $\beta$ in the EMT mechanism $(20,21)$. Estrogen Receptors in this research were not only in PT, but ER immunoexpression was also assessed in FA samples, and significant differences were found with various gradations of PT. This reinforces the role of ER in changes in epithelial cells in the breast gland. In this study, significant differences were found in the loss of ER expression in malignant PT and borderline PT compared with FA and benign PT. This is inversely proportional to the Snail-1 expression, where high expression is found at borderline PT and malignant PT. Interestingly, Snail-1 is found in epithelial cells in the FA, so further research is needed to prove the EMT theory about this change.

\section{ACKNOWLEDGEMENT}

We would like to thank the Faculty of Medicine and Health Science, Jambi University, for the research funding under contract number 929/UN21.17/LT/2018 April 16, 2018.

5. Akrida I, Bravou V, Nikou S, et al. Expression of Epithelial to Mesenchymal Transition-related Transcription Factor ZEB1 in Phyllodes Breast Tumours: An Immunohistochemical Study. Archiv für Pathologische Anatomie und Physiologie und für Klinische Medicin. 2015; 467(1): S11.

6. Kwon JE, Jung WH, and Koo JS. Molecules Involved In Epithelial-mesenchymal Transition and Epithelialstromal Interaction in Phyllodes Tumors: Implications for Histologic Grade and Prognosis. Tumor Biology. 2012; 33(3): 787-798.

7. Smith BN, Burton LJ, Henderson V, et al. Snail Promotes Epithelial Mesenchymal Transition in Breast Cancer Cells in Part Via Activation of Nuclear ERK2. PLOS ONE. 2014; 9(8): e104987. 
8. Tian M and Schiemann WP. TGF-B Stimulation of EMT Programs Elicits Non-genomic ER- $\alpha$ Activity and Antiestrogen Resistance in Breast Cancer Cells. Journal of Cancer Metastasis and Treatment. 2017; 3(8): 150160.

9. Kang BJ, Jo KW, Park TS, et al. Causes and Predictive Factors Associated with "Diagnosis Changed" Outcomes in Patients Notified as Tuberculosis Cases in a Private Tertiary Hospital. Tuberculosis and Respiratory Diseases. 2013; 75(6): 238-243.

10. Wu Y and Zhou BP. Snail. Cell Adhesion \& Migration. 2010; 4(2): 199-203.

11. Wang Y, Shi J, Chai K, Ying X, and Zhou BP. The Role of Snail in EMT and Tumorigenesis. Current Cancer Drug Targets. 2013; 13(9): 963-972.

12. Mo XT, Zhou WC, Cui WH, et al. Inositol-requiring Protein 1 - X-box-binding Protein 1 Pathway Promotes Epithelial-mesenchymal Transition Via Mediating Snail Expression in Pulmonary Fibrosis. The International Journal of Biochemistry and Cell Biology. 2015; 65: 230-238.

13. Poblete CE, Fulla J, Gallardo M, et al. Increased SNAIL Expression and Low Syndecan Levels are Associated with High Gleason Grade in Prostate Cancer. International Journal of Oncology. 2014; 44(3): 647-654.

14. Fendrich V, Maschuw K, Waldmann J, et al. Epithelialmesenchymal Transition is a Critical Step in Tumorgenesis of Pancreatic Neuroendocrine Tumors. Cancers (Basel). 2012; 4(1): 281-294.

15. Wu $\mathrm{Y}$, Sarkissyan $\mathrm{M}$, and Vadgama J. EpithelialMesenchymal Transition and Breast Cancer. Journal of Clinical Medicine. 2016; 5(2): 13.

16. Gurzu S, Turdean S, Kovecsi A, Contac AO, and Jung I. Epithelial-Mesenchymal, Mesenchymal-Epithelial, and Endothelial-Mesenchymal Transitions in Malignant Tumors: An Update. World Journal of Clinical Cases. 2015: 3(5); 393-404.

17. Shao R, Shi J, Liu H, et al. Epithelial-to-Mesenchymal Transition and Estrogen Receptor a Mediated Epithelial Dedifferentiation Mark the Development of Benign Prostatic Hyperplasia. Prostate. 2014; 74(9): 970-982.

18. Wik E, Ræder MB, Krakstad C, et al. Lack of Estrogen Receptor- $\alpha$ is Associated with EpithelialMesenchymal Transition and PI3K Alterations in Endometrial Carcinoma. Clinical Cancer Research. 2013; 19(5): 1094-1105.

19. Kim YH, Kim GE, Lee JS, et al. Hormone Receptors Expression in Phyllodes Tumors of the Breast. Analytical and Quantitative Cytology and Histology/The International Academy of Cytology [and] American Society of Cytology. 2012; 34(1): 41-48.

20. Fairuz and Suryawati B. Hubungan Imunoekspresi ER$\alpha, E R-6$, dan PR dengan Gradasi pada Tumor Filodes Payudara. Jurnal Kedokteran Brawijaya. 2017; 29(3): 238-243.

21. Bouris P, Skandalis SS, Piperigkou Z, et al. Estrogen Receptor Alpha Mediates Epithelial to Mesenchymal Transition, Expression of Specific Matrix Effectors and Functional Properties of Breast Cancer Cells. Matrix Biology: Journal of the International Society for Matrix Biology. 2015; 43: 42-60. 